\title{
Amaranth Plant: Protects Climate, Health and Development by Controlling Root-Knot Disease
}

Subhas Chandra Datta ${ }^{1 *}$, Ranita Das ${ }^{1}$, Kingshuk Chatterjee ${ }^{1}$, Bikram Mondal ${ }^{1}$ and Rajnarayan Das ${ }^{2}$

${ }^{1}$ Eco-Club Research Unit, Kanchannagar DN Das High School (HS), Kanchannagar, Burdwan, West Bengal, India

${ }^{2}$ Bardhaman Science Centre, Ramna Maidan, Baburbag, Burdwan, West Bengal, India

\begin{abstract}
Plant diseases, caused by pathogens, significantly reduce food production particularly in the developing world. Syntheticand chemical- pesticides are the most effective means of control, but they are expensive and not environment friendly. Population growth and rapid urbanization are putting considerable pressure on water available for irrigation. The "evils" of synthetic- and chemical- pesticides has been a major concern to environmentalists. To move forward, it will require new and more efficient solutions, technologies and products. Our best endeavor is to focus on the edible Amaranth which may have important economic implications for agriculture in future. In a well-protected garden of Kanchannagar DN Das High School (HS), Government of West Bengal, naturally-infested with Meloidogyne incognita, Kofoid and White, Chitwood, amaranth (Amaranthus viridis L.) cv. CO-1 was intercropped with okra (Abelmoschus esculentus L. Moench) cv. Ankur-40 to determine the effects on nematode populations. The nematode population varied from 25732639 per $200 \mathrm{~g}$ of soil. Amaranth was planted in between every two okra plants. All the plants were harvested at 70 days after plantation. Of the two plant species, amaranth received maximum infection in terms of root gall number, nematode population in root, root protein content and plant growth parameters. Though both the amaranth and okra plants were susceptible to root-knot nematodes. Amaranth was more susceptible than okra in terms of root-gall number nematode population in root and root protein content. Okra has also the lowest root-gall number and nematode population in root. While $M$. incognita population increased significantly both in soil as well as in roots in 70 days in the monoculture. But amaranth showed the highest intensity of nematode infection. These results suggest that root-knot disease easily and effectively controlled by the use of amaranth plants as "trap crop" for root-knot nematodes intercropped with okra plants in the naturally root-knot infested field. As intercrop amaranth could be harvested at frequent intervals to keep the nematode population to a minimum level. This way amaranth could serve as highly effective Climate Friendly Catch Crop protecting other crops from invading larvae. The farmers would be benefited double; by controlling root-knot nematodes in the naturally infected agricultural field, and by buying and selling the edible amaranth plant regularly from the intercropped agricultural field. Intercropped amaranth also improves the plant growth effectively which directly increase photosynthesis rate and significantly reduce $\mathrm{CO}_{2}$ in the environment and it would not only be easier way, easily available, cheap but also conserve our biodiversity which will contribute towards "Sustainable Climate, Health and Development by controlling root-knot diseases which is sometime devastating to all kinds of natural and artificial vegetation."
\end{abstract}

Keywords: Intercropping; Amaranth; Okra; Root-knot; Naturallyinfested field; Climate friendly catch crop

\section{Introduction}

Climate change is caused by factors such as biotic processes, variations in solar radiation received by earth plate tectonics, and volcanic eruptions. We think it is too vast a topic to be discussed. Our best endeavor is to focus on the Edible Amaranth Plant that protects Climate, Health and Development by controlling root-knot diseases which is sometime devastating to all kinds of natural and artificial vegetation $[1,2]$.

\section{Significant problems}

Plant diseases, caused by pathogens, significantly reduce food production particularly in the developing world where farmers have little knowledge of pests. Plant parasitic nematodes, especially rootknot nematode $M$. incognita have a wide range of host and causes root-knot disease. However, the susceptibility of different host to these nematodes varies considerably [3-5]. The root-knot disease of mulberry (Morus alba L.) caused by Meloidogyne incognita (Kofoid and white, Chitwood, 1949) is epidemic affecting more than $80 \%$ plantation in different parts of India [6,7]. This disease reduces plant growth, leaf-and fruit- yield, leaf-and fruit-protein content significantly. In sericulture, mulberry is an economical plant because silk production depends on the nutritive quality of the leaves which is hampered by various pathogen attacks like nematodes, fungus, virus, bacteria and insects etc. [8-11]. Recently, synthetic- and chemical- pesticides are the most effective means of control, but they are expensive and not environment friendly also. The "evils" of synthetic- and chemicalpesticides has been a major concern to environmentalists. The use of chemical pesticides may achieve a measure of control of those plants diseases but there remains the problem of residual toxicity in the treated plants and this toxicity results reducing palatability of the leaves to the feeding silkworm larvae; reduction in growth of the larvae and also in silk production. These are serious issues which directly cause crises of financial losses, food productions, and climatic changes, but in combination, their impact could be catastrophic for the global economy $[12,13]$.

*Corresponding author: Subhas Chandra Datta, Eco-Club Research Unit, Kanchannagar DN Das High School (HS), Kanchannagar, Burdwan-713 102, West Bengal, India, Tel: 09832267610; E-mail: dattasubhas@rediffmail.com

Received November 04, 2015; Accepted December 18, 2015; Published January 06, 2016

Citation: Datta SC, Das R, Chatterjee K, Mondal B, Das R (2016) Amaranth Plant: Protects Climate, Health and Development by Controlling Root-Knot Disease. J Environ Anal Toxicol 6: 341. doi:10.4172/2161-0525.1000341

Copyright: $\odot 2016$ Datta SC, et al. This is an open-access article distributed under the terms of the Creative Commons Attribution License, which permits unrestricted use, distribution, and reproduction in any medium, provided the original author and source are credited. 


\section{Role and importance of climate change in the world agricultural scenario}

The relationship between water and other development-related sectors such as population, energy, food, and environment, and the interactions among them require analysis, as they together will determine future food security and poverty reduction. In addition, the study of Irrigated Agriculture Indicators has played an important role in agricultural water management since past years, and in future. What is the tendency to cultivate plants for designing cropping intensity in irrigated area? [14]. To provide food for sustainable development, agricultural water management must be taken into account. Due to the limited nature of water resources, the role of macroeconomic policies in agricultural water management is vital and undeniable. Assessment of cropping intensity helps to managers and experts for an accurate scheduling to dedicate water resources and designing a suitable cropping pattern for farmers. That study aims to investigate the variations of cropping intensity in Asia-Oceania, Europe, and Americas from 1962 to 2011 by using information of Food and Agriculture Organization (FAO) [14-18]. Finally, the results indicate that attention to only commercial goals should be reduced, trial and error policies should be avoided and expert comments be applied to the irrigation systems for any crop to achieve sustainable agriculture in future [14].

Assessment of Important Factors for Water Resources Management in European Agriculture where the paper aims to estimate the areas equipped for irrigation and the desirability of agricultural water management in Europe [19]. For that purpose, all necessary information was gathered from Food and Agriculture Organization of the United Nations (FAO) and cross referenced using the World Bank Group (WBG). The selected indices were analyzed for all 46 countries and the extent of areas equipped for irrigation of cultivated areas was estimated by two different formulas, using the other nine indices. The results demonstrate that value of relative error is less than $20 \%$. In addition, an average index was calculated using two methods to assess each country's conditions for agricultural water management [19-23].

It is highlighted that production is more sensitive to climate than to weather and that it is very sensitive to cropping intensity. In addition to identifying potential gaps, results provide insight into the probable long- and short-term ecosystem response to changes in climate, weather, and cropping. In addition, cropping intensity has a highlighted role in agricultural water management during past years and future [14-23].

\section{Possible solutions}

To move forward, it will require new and more efficient solutions, technologies and products. Climate change and resource productive economies are now universally recognized as a significant global environmental challenge. To meet the challenge of the problems, a number of plant bio-nematicides as crude and pure compound, though effective and easily biodegradable but they are not easily available in large quantities from natural sources and isolation of only a small quantity of an effective metabolites requires huge quantities of plant materials [6-14]. This would result in rapid depletion of natural resources, particularly in tropical regions. Indiscriminate use of plant resources have already created problem of biodiversity conservation in the world and not cost effective [6-24].

Bio-nematicides from animal origin (like nematode extract, gall protein) reduce nematodes infestation in different plants and root callous by using their defense-response against nematode infection. But it remains as a problem for field application and not cost effective $[25,26]$.

Then, we think that 'Homeopathy' may solve all the above mentioned problems. Homeopathic medicines; Cina, prepared from the flowering meristems of Artemisia nilagirica (Clarke) pamp and Aakashmoni, prepared from the funicles of Acacia auriculiformis A. Cunn, are highly effective in ameliorating mulberry diseases; rootknot [Meloidogyne incognita (Kofoid and White) Chitwood], leaf spot [Cercosporam moricola (Cooke)], powdery mildew [Phyllactinia corylea (Pers.) Karst], mosaic disease (mosaic virus) and tukra disease [Maconellicoccus hirsutus (Green)] [2,10-12,27,28].

Recently, we select Amaranth which has important economic implications for agriculture. It is used in tropical and subtropical countries for human nutrition both as vegetables and grains and also as animal feed. It has been reported to have some pharmacological properties [29]. Amaranth also has clusters of nutty edible seeds, which can be eaten as snacks or used in biscuits. A porridge can be made by boiling the seeds in water [29].

In that study we explored the relative attractiveness of different 4- plant species of crops for M. incognita and this would help in identifying the susceptible plants for possible use as catch crop [5]. We have observed that amaranth (Amaranthus viridis L.) is more susceptible than cucumber, lady's finger and cowpea. While plants relatively resistant to root-knot nematodes can be profitably used for crop rotation, those highly susceptibility to the plant parasitic nematodes can be cultivated as cover crops with other cash crops [5].

In another study, amaranth and mulberry were planted alternately in a large circular vessel; $M$. incognita larvae $\left(\mathrm{J}_{2}\right)$ were applied as inoculums at the center of the ring so that all the plants were equidistant from the larvae. We see that amaranth could serve as highly effective cover crop protecting other susceptible crops from invading larvae $[9,13]$.

In another micro-plot experiment, we also see that Amaranth (Amaranthus viridis L.) Cv. CO-1 and okra (Abelmoschus esculentus L. Moench) Cv. Ankur - 40 were alternately grown in a plot; second stage root-knot nematode - Meloidogyne incognita (Kofoid and White) Chitwood juveniles $\left(\mathrm{J}_{2}\right)$ were applied as an inoculum in the soil of the plot where amaranth could serve as highly effective catch crop protecting other susceptible crops from invading larvae [30].

\section{The most appropriate, economic and sustainable solutions}

To find out most suitable solution, which has been observed from previous experiment that Amaranth is more susceptible to root-knot nematodes than okra? [30]. The previous works were restricted on a limited area in the form of circular- or micro plot- experiment and it was not possible to apply them to other regions of naturally rootknot infected field condition. A field trial, was planned in order to further confirm the use of amaranth (A. viridis L., Cv. CO-1) as "trap crop" for root-knot nematodes intercropped with okra (A. esculentus L. Moench) Cv. Ankur - 40 in the naturally root-knot infected field condition. Therefore, this study provides an opportunity for naturally root-knot infected field that have not been studied in the previous studies. Our main aim was to investigate new and more efficient solutions, technologies and products for controlling root-knot disease by using amaranth plant which indirectly influence the Climate change and resource productive economies. 


\section{Materials and Methods}

\section{Location of the field trial}

The field experiment was carried out at the well protected garden of Kanchannagar DN Das High School (HS), Government of West Bengal, where temperature was $28 \pm 5^{\circ} \mathrm{C}$, relative humidity was $75 \pm 5 \%$ and soil $\mathrm{pH} 5.8$, measuring $0.02 \mathrm{~h}$ land, naturally-infested with root-knot disease $[6,8]$. Burdwan is extends from $22^{\circ} 56^{\prime}$ to $23^{\circ} 53^{\prime}$ North latitude and from $86^{\circ} 48^{\prime}$ to $88^{\circ} 25^{\prime}$ East longitudes. The experimental field has sandy alluvial soil, well drained and slightly acidic in nature. And average rainfall was 150 millimetre. The experiment was conducted from 2012 to 2015 by the secondary- and higher secondary- students of Kanchannagar DN Das High School (HS), Burdwan, Government of West Bengal. These experimental fields were randomized in the infested field by using a completely randomized block design. All the data were counted for statistical analysis by t-test.

\section{Preparation of field}

Soil was interchanged to keep the nematode population as uniform as possible with mixing manure $(2: 1 \mathrm{vol} / \mathrm{vol})$. The nematode population varied from 2573-2639 per $200 \mathrm{~g}$ of soil. Soil samples were taken at random for estimation of nematode population $[8,31,32]$. This experimental field was randomized in the infested field by using a completely randomized block design. All the data were counted for statistical analysis by t-test.

\section{Plantation}

Aseptically germinated seeds of amaranth (Amaranthus viridis L. Cv. CO-1) and okra (Abelmoschus esculentus L. Cv. Ankur- 40) were planted alternately with a gap of $25 \mathrm{~cm}$. Since amaranth was a slow growing plant, it was planted 15 days earlier than the okra plant $[9,13,30]$. All the data were counted for statistical analysis by t-test.

\section{Harvesting}

Seventy days after plantation of okra, all the plants were uprooted and the following parameters of growth and nematode infection were recorded : length of shoot and root, fresh weight of shoot and root, root gall number, nematode population per $2 \mathrm{~g}$ of root and $200 \mathrm{~g}$ soil and root protein content. Three samples of root from each species of plants were taken at random and the total protein fraction in each sample was estimated $[33,34]$. All the data were counted for statistical analysis by t-test.

\section{Results}

Table 1 shows the use of amaranth as trap crop for $M$. incognita intercropped with okra plants on naturally $M$. incognita infested field $(\mathrm{P}<0.1$ by ' $\mathrm{t}$ ' - test $)$. Both the amaranth and okra plants were susceptible to root-knot nematodes. Amaranth was more susceptible than okra in terms of root-gall number nematode population in root and root protein content. Okra has also the lowest root-gall number and nematode population in root (Table 1). While M. incognita population increased significantly both in soil as well as in roots in 70 days in the monoculture. But amaranth showed the highest intensity of nematode infection.

\section{Discussion}

It is evident from the observation that amaranth was more susceptible to $M$. incognita than okra plant. This does not mean that okra is resistant to root-knot nematodes. In contrary, okra is a very good host of this nematodes. However, root-knot nematodes preferred to feed on amaranth rather than okra when it had a choice. It can be assumed that the relative size and biomass of the two root systems are responsible for the difference in susceptibility between the two plant species. Here the amaranth root system colonizes and occupies the large area, it is likely that the plant parasitic nematodes will preferably be found in its roots $[5,9,13,30]$.

And the positive effects of growth of both okra and amaranth plans may be responsible for defense resistance against other plants pathogens $[2,25,26]$. Plants growth directly increase photosynthesis rate by increasing stomata- activity, conserve solar energy in the glucose and significantly reduce $\mathrm{CO}_{2}$ in the climate. So we can say that both plants might have induced synthesis of many new proteins which have stimulated increased photosynthesis rate, stomata- activity and water retention capacity plants $[2,25,26,35]$. These results may suggest that plant diseases (like nematodes, fungus, virus, bacteria and insects, etc.) might be effectively controlled by the amaranth plant which directly enriches agriculture sector.

\section{Conclusion}

Thus amaranth could serve as a good catch crop there by reducing $M$. incognita infection of other vegetables. It can also be cultivated as intercrop with many highly economical plants as substitute for chemical control as this possess health hazard due to residual toxicity in leaves and soil to many economically important larvae, herbivores, soil micro- and macro- fauna, and man. As intercrop amaranth could be harvested at frequent intervals to keep the nematode population to a minimum level. This way amaranth could serve as highly effective Climate Friendly Catch Crop protecting other crops from invading larvae. The farmers would be benefited double; by controlling rootknot nematodes in the naturally infected agricultural field, and by buying and selling the edible amaranth plant regularly from the intercropped agricultural field. We easily enrich our agricultural economy, protect our climate from pollution, conserving solar energy by photo synthesis of plants, reducing $\mathrm{CO}_{2}$ by increasing $\mathrm{O}_{2}$ which resist global warming, and also conserve our biodiversity. This costeffective eco-friendly amaranth is easily available, high environmental tolerant, biodegradable, non-phytotoxic and non-pollutant. It can be used as Cover plant. It conserves our biodiversity contributing towards "Sustainable Climate Health and Development" and It is the most appropriate, economic and sustainable solution in the recent time. And last but not least Amaranth may have important economic implications in agriculture.

\begin{tabular}{|c|c|c|c|c|c|c|c|c|}
\hline \multirow{2}{*}{ Plots } & \multicolumn{2}{|l|}{ Length (cm) + } & \multicolumn{2}{|c|}{ Fresh Weight $(\mathrm{g})+$} & \multirow{2}{*}{ Root Galls/Plant ${ }^{*}+$} & \multirow{2}{*}{\multicolumn{2}{|c|}{$\begin{array}{l}\text { Nematode Population + Root }(2 \mathrm{~g}) \text { Soil } \\
(200 \mathrm{~g})\end{array}$}} & \multirow{2}{*}{$\begin{array}{l}\text { Root Protein Content } \\
(\%)+\end{array}$} \\
\hline & Shoot & Root & Shoot & Root & & & & \\
\hline \begin{tabular}{|l|} 
Monoculture \\
Amaranth Okra
\end{tabular} & $\begin{array}{l}54.90 \mathrm{a} \pm 1.54 \\
44.70 \mathrm{~b} \pm 1.47\end{array}$ & $\begin{array}{l}12.40 \mathrm{~b} \pm 0.22 \\
14.50 \mathrm{a} \pm 0.25\end{array}$ & $\begin{array}{l}86.00 a \pm 2.30 \\
63.00 b \pm 1.15\end{array}$ & $\begin{array}{l}59.80 a \pm 1.99 \\
13.30 b \pm 0.16\end{array}$ & $\begin{array}{l}4460.00 a \pm 23.00 \\
22.00 b \pm 0.10\end{array}$ & $\begin{array}{l}1510.00 a \pm 18.00 \\
73.00 b \pm 11.65\end{array}$ & $\begin{array}{l}97.00 \mathrm{a} \pm 2.85 \\
97.00 \mathrm{a} \pm 2.85\end{array}$ & $\begin{array}{l}6.03 a \pm 0.03 \\
4.65 b \pm 0.02\end{array}$ \\
\hline
\end{tabular}

a,b: Significant difference in a column by t-test $(P<0.01)$ in the same column; +: Mean of 10 plants replicated thrice; *: Plants naturally infected with $2573-2639$ per $200 \mathrm{~g}$; $M$. incognita juveniles $\mathrm{J}_{2}$ per $200 \mathrm{~g}$ of soil and harvested 70 days after okra plantation

Table 1: Use of amaranth plants as trap crop for $M$. incognita intercropped with Okra plants in a field. 
Citation: Datta SC, Das R, Chatterjee K, Mondal B, Das R (2016) Amaranth Plant: Protects Climate, Health and Development by Controlling RootKnot Disease. J Environ Anal Toxicol 6: 341. doi:10.4172/2161-0525.1000341

\section{Acknowledgements}

We thank World Vision of India, Burdwan, Basudev Mondal, Assistant Teache of Kanchannagar DN Das High School and Rtd. Professor NC Sukul, Department of Zoology, Visva-Bharati University, Santiniketan-731 235, West Bengal for all kinds of support. We are also thankful to Dr. N Banerjee, Plant Biotechnology Laboratory, Department of Botany, Visva-Bharati University, Santiniketan-731 235 West Bengal, India for help and facilities.

\section{References}

1. Milesi C, Samanta A, Hashimoto H, Kumar KK, Ganguly S, et al. (2010) Decada variations in NDVI and food production in India. Remote Sens 2: 758-776.

2. Datta SC, Datta R (2012) Homeopathic medicines protect environment, health and development by controlling mulberry diseases. J Tra and Cli natu.

3. McSorley R, Dickson DW, deBrito JA (1994) Host status of selected tropical rotation crops to four populations of root-knot nematodes. Nematropica 24: 45-53.

4. Mosjidis JA, Rodrigo Rodriguez-Kabana, Weaver CF, King PS (1994) Reaction of vicia species to meloidogyne arenaria race 2 and Heterodera glycines race 4. Nematropica 24: 1-5.

5. Datta SC, Datta R, Sukul A, Sukul NC, Sinhababu SP (2000) Relative attractiveness of four species of vegetable crops for Meloidogyne incognita. Environ Ecol 18: 233-235.

6. Datta SC, Sinhababu SP, Sukul NC (1997) Improved growth of silkworms from effective treatment of mulberry diseases by Acacia auriculiformis extract. Sericol 37: 707-715.

7. Sukul NC (1992) Plant antagonistic to plant parasitic nematodes. Indian Rev Life Sci 12: 23-52.

8. Data SC (2005) Plant parasitic nematodes - an agricultural problem and its solutions. The Visva-Bharati Quart 11: 89-100.

9. Datta SC (2005) Possible use of amaranth as catch crop for root-kno nematodes intercropped with mulberry. J Environ Sociobiol 2: 61-65.

10. Datta SC (2006) Effects of Cina on root-knot disease of mulberry. Homeopathy 95: 98-102.

11. Datta SC, Datta R (2006) Liquid homeopathic medicine Cina enriches sericulture industry. J Environ Sociobiol 3: 55-60.

12. Datta SC, Datta R (2011) Control of root-knot disease of mulberry by homeopathic medicines: aakashmoni [Mt, 30c, 200c \& 1000c] prepared from the funicles of acacia auriculiformis. hpathy ezine.

13. Datta SC, Datta R (2007) Intercropping amaranth with mulberry for managing root-knot nematodes and improving sericulture. Sericol 47: 297-306.

14. Valipour M (2015) What is the tendency to cultivate plants for designing cropping intensity in irrigated area? Adv in Water Sci and Tech 02: 01-12.

15. Valipour M (2014) Irrigation status of Americas. Acta Adv Agric Sci 2: 56-72.

16. Valipour M (2014) Variations of irrigated agriculture indicators in different continents from 1962 to 2011. Adv in Water Sci and Tech 1: 1-14.
17. Valipour M, Gholami Sefidkouhi MA, Eslamian S (2015) Surface irrigation simulation models: a review. Int $\mathrm{J}$ of Hydrology Sci and Tech 05.

18. Valipour M (2014) Handbook of irrigation engineering problems. Foster City (CA): OMICS Group eBooks.

19. Valipour M (2015) Assessment of Important Factors for water resources management in european agriculture. $\mathrm{J}$ of water resource and hydraulic eng 4: 171-180.

20. Valipour M (2014) Handbook of water engineering problems. Foster City (CA): OMICS Group eBooks

21. Valipour M (2014) Prediction of irrigated agriculture in Asia Pacific using FAO indices. Acta Adv Agric Sci 2: 40-53.

22. Valipour M (2014) Pressure on renewable water resources by irrigation to 2060. Acta Adv Agric Sci 2: 32-42.

23. Valipour M (2014) Future of agricultural water management in Europe based on socioeconomic indices. Acta Adv Agr Sci 2: 1-18.

24. Datta SC, Datta R (2007) Increased silk production by effective treatment of naturally infected root-knot and black leaf spot diseases of mulberry with acaciasides. J Environ Sociobiol 4: 209-214.

25. Datta SC, Sinhababu SP, Banerjee N, Ghosh K, Sukul NC (1998) Melodogyne incognita extract reduces melodogyne incognita infestation in tomato. Ind $J$ Nematol 28: 1-5.

26. Datta SC, Datta R, Sinhababu SP, Sukul NC (1998) Acaciasides and rootknot nematode extract suppress Melodogyne incognita infection in lady's finger plants. Pro Nat Sem Environ Biol 98: 205-209.

27. Datta SC, Datta R (2013) Efficacy of homeopathic medicine-Aakashmoni as potential bio-agent against various plant pathogens. Biochem and Pharmacol.

28. Datta SC, Datta R (2012) Homeopathic medicine Aakashmoni 200C contro mulberry diseases enriching sericulture. J Curr Chem Pharm Sc 2: 37-49.

29. Maiyo ZC, Ngure RM, Matasyoh JC, Chepkorir R (2010) Phytochemical constituents and antimicrobial activity of leaf extracts of three Amaranthus plant species. Afr J Biotec 9: 3178-3182.

30. Datta SC (2006) Possible use of amaranth as catch crop for root-knot nematodes intercropped with okra. Phytomorph 56: 1-3.

31. Christie JR, Perry VG (1951) Removing nematodes from soil. Proc Helm Soc Wash 18: 106-108.

32. Sukul NC (1987) Soil and plant nematodes. WB State Book Board Publ. Cal $0-271$

33. Lowry OH, Rosebrough NJ, Farr AL, Randall RJ (1951) Protein measurement with the Folin-Phenol reagent. J Biol Chem 193: 265-275

34. Chatterjee A, Sukul NC (1981) Total protein of galled roots as an index of rootknot nematode infestation of lady finger plants. Phytopathol 71: 372-274.

35. Sukul NC, Sinhababu SP, Datta SC, Nandi B, Sukul A (2001) Nematotoxic effect of Acacia auriculiformis and Artemisia nilagirica against root-knot nematodes. Allelopth J 8: 65-72. 